\title{
CORRIGENDUM
}

\section{UVA radiation causes DNA strand breaks, chromosomal aberrations and tumorigenic transformation in $\mathrm{HaCaT}$ skin keratinocytes}

K Wischermann, S Popp, S Moshir, K Scharffetter-Kochanek, M Wlaschek, F de Gruijl, W Hartschuh, R Greinert, B Volkmer, A Faust, A Rapp, P Schmezer and P Boukamp

Oncogene (2008) 27, 6790; doi:10.1038/onc.2008.375

Correction to: Oncogene (2008) 27, 4269-4280; doi:10.1038/onc.2008.70; published online 31 March 2008.

Since the publication of the above paper, the authors have identified an error in the author list; the name of the fourth author was misspelt. The corrected author list is shown above.

In addition to the funding sources mentioned in the paper, this study was also in part supported by the Bmbf 03NUK003A (UV-Strahlenschaeden) (to PB, KS-K and $\mathrm{RG}$ ). 